\title{
BURLE MARX NO RECIFE: RESTAURO DO JARDIM DO AEROPORTO DOS GUARARAPES COMO BEM PATRIMONIAL
}

\author{
BURLE MARX IN RECIFE: THE RESTORATION OF THE \\ GUARARAPES AIRPORT GARDEN AS CULTURAL HERITAGE
}

\author{
Ana Rita Sá Carneiro* \\ Cristina Castel-Branco** \\ Joelmir Marques da Silva***
}

\begin{abstract}
RESUMO
Este artigo apresenta a experiência do workshop "Restauro de Jardins Históricos", ocorrida em 2012 na cidade do Recife, no Nordeste do Brasil, tendo como objeto o jardim do aeroporto dos Guararapes, denominado de praça Ministro Salgado Filho, projetado pelo paisagista Roberto Burle Marx em 1957 e que faz parte de um conjunto de jardins concebidos pelo paisagista em Recife entre 1935 e 1958. O estudo desse jardim, que obteve recentemente o título de patrimônio cultural nacional, pretende ser uma referência para futuras ações de restauro no âmbito da conservação urbana no Brasil.

Palavras-chave: Jardim histórico. Restauração. Conservação.
\end{abstract}

\section{ABSTRACT}

This paper reports a workshop on historic garden restoration that took place in the city of Recife, northeast Brasil in 2012 by focusing the Guararapes airport garden called Ministro Salgado Filho square which was

\footnotetext{
* Arquiteta pela Universidade Federal de Pernambuco (UFPE). Professora do curso de Arquitetura e Urbanismo, da pós-graduação em Desenvolvimento Urbano e coordenadora do Laboratório da Paisagem da UFPE. Membro do Centro de Estudos Avançados da Conservação Integrada (CECI). Conselheira da Organização das Nações Unidas para a Educação, a Ciência e a Cultura (Unesco) no Comitê Internacional de Paisagens Culturais. Bolsista de Produtividade em Pesquisa do CNPq nível 1C. Rua Jader de Andrade, 109, apt. 302, 52061-060, Casa Forte, Recife, PE, Brasil. anaritacarneiro@hotmail.com

** Arquiteta paisagista pela Universidade de Lisboa (Ulisboa). Professora do curso de Arquitetura Paisagística do Instituto Superior de Agronomia (ISA), da Ulisboa e da pós-graduação em Arquitetura Paisagista e Ecologia Urbana, programa de doutorado entre as Universidades Técnicas de Lisboa, de Coimbra e do Porto. Responsável pelo ACB Arquitetura Paisagística. Conselheira da Unesco no Comitê Internacional de Paisagens Culturais. Rua da Correnteza, 1, 1400-077, Lisboa, PT. acbpaisagem@acb-arqpaisagista.pt

*** Biólogo pela Universidade de Pernambuco (UPE). Mestre em Desenvolvimento Urbano pela Universidade Federal de Pernambuco (UFPE) e em Diseño, Planificación y Conservación de Paisajes y Jardines pela Universidad Autónoma Metropolitana (UAM-Azcapotzalco), México. Doutorando em Desenvolvimento Urbano pela Universidade Federal de Pernambuco (UFPE). Pesquisador do Laboratório da Paisagem da UFPE. Bolsista CAPES e CNPq (Doutorado Sanduíche). Rua Ademar de Barros, 220, Timbi, 54774-395, Camaragibe, PE, Brasil.

joelmir_marques@hotmail.com
} 
designed by Roberto Burle Marx in 1957. It is part of the set of gardens he designed in Recife from 1935 to 1958. The study of this garden, which was, recently, protected as a brazilian cultural heritage intends to be a reference on garden restoration proposals in the future concerning urban conservation in Brasil. Keywords: Historic garden. Restoration. Conservation.

\section{INTRODUÇÃO}

A obra de Roberto Burle Marx é considerada um expoente da arquitetura paisagística do período modernista. Michel Racine (1994), no artigo "Roberto Burle Marx: o elo que faltava", afirma:

Roberto Burle Marx, com uma obra que começa nos anos 30 prosseguindo até os dias de hoje, acha-se em posição privilegiada para ajudar-nos, a nós, europeus, a retomar o fio da história dos jardins, a lançar pontes sobre a fratura de uma época em que jardim e paisagem só tinham sentido para um número restrito de amadores. Seu papel de intermediário cultural é constante. De um lado, ele leva para o Sul as mensagens da Bauhaus, dos CIAM - e posteriormente a mensagem ecológica -, do outro, enfatiza incansavelmente a especificidade da paisagem natural brasileira. [...] Na medida de sua evolução, de seu conhecimento das plantas e da evolução da ideia de natureza [...] aumenta ele sem cessar a paleta vegetal do jardineiro chegando mesmo a tornar-se portador, em seu país, de um olhar ecológico [...] Mas o mais surpreendente no modernismo brasileiro é que é um movimento-modernista-com-jardim. (RACINE, 1994, p. 114).

Racine ressalta o domínio do conhecimento de Burle Marx não só no campo da arquitetura como também no da botânica, fazendo com que o jardim moderno brasileiro seja entendido como composição arquitetônica. Burle Marx caminhou ao lado de Lucio Costa, referência maior da arquitetura moderna no Brasil, na concepção dos espaços arquitetônicos de Brasília, como uma cidade moderna em que os jardins são parte da criação arquitetônica e urbanística e representações da paisagem regional.

Sobre a afirmação de Racine aqui colocada, sobrepõe-se, ainda, a ideia de Burle Marx de jardim-pintura, como obra de arte, tão bem sintetizada por Jacques Leenhardt (1994, p. 9-13):

Na verdade, dos anos vinte aos dias de hoje, Burle Marx jamais deixou de pintar, e o conhecimento de seu trabalho pictórico ilumina de modo esclarecedor suas realizações paisagísticas [...] Burle Marx teria retransposto para a pintura a própria experiência do jardim, experiência marcada ao mesmo tempo pela imposição das caminhadas e a liberdade de evasão do olhar que dá ao corpo uma ubiquidade imaginativa e sensível.

Na visão de Leenhardt, a obra de Burle Marx se faz do diálogo entre a arte da pintura e a de fazer jardim (e vice-versa) como experiências que se cruzam e se engrandecem. Aprofundar esses estudos torna-se cada dia mais necessário para divulgar o conteúdo 
artístico e cultural desse modo de fazer jardins, passando a ser entendidos como jardins históricos, ainda recentes, que precisam ser mantidos e protegidos dos males que o crescimento urbano costuma infligir aos espaços abertos. Em 2000, Charles Birnbaum coordenou as atas da Conferência Preserving the Modern Landscape, chamando atenção para o perigo de perder essa herança, pois as "[...] estratégias para a preservação e manutenção do patrimônio modernista criado durante o século XX não são uma prioridade para as instituições responsáveis". (CASTEL-BRANCO, 2004, p. 100-117).

Essa preocupação levou o Laboratório de Paisagem da Universidade Federal de Pernambuco/UFPE a organizar jornadas de trabalho em torno do restauro dos jardins modernistas de Roberto Burle Marx construídos no Recife para serem conservados como jardins históricos. Referindo-se às questões que levaram ao aparecimento de uma peça legal internacional, a Carta de Florença de 1981, que consigna as regras básicas do restauro de jardins históricos, a especialista Carmen Añón Feliú afirma:

Sem dúvida que todas estas correntes estavam necessitadas de um apoio instrumental oficial. $\bigcirc$ jardim tinha que atravessar a fronteira entre a prática e uns poucos eleitos e a intervenção pública legislativa. [...] Em primeiro lugar o estabelecimento de leis precisas que incluíssem os jardins como bens a conservar. (ICOMOS, 2006, s/p).

A Carta de Florença, redigida pelo Comitê Internacional de Jardins e Paisagens Culturais, que funciona como assessor da United Nations Organization for Education, Science and Culture (UNESCO) para as paisagens culturais patrimônio mundial, foi instrumento seminal para a consolidação da teoria e prática do restauro de jardins patrimoniais, tendo papel fundamental na salvação de muitos jardins. Logo após a ratificação dessa Carta, em 1984, a recuperação de jardins e a sua gestão converteram-se, em muitos países, em uma disciplina universitária.'

No Brasil, a restauração e a conservação de jardins históricos começaram a ser discutidas em 2001, com base na Carta de Florença, pelo Laboratório da Paisagem/ UFPE e pela Prefeitura da Cidade do Recife, tendo como objetivo a intervenção na praça Euclides da Cunha (1935), na praça do Derby (1937) e na praça Faria Neves (1958), todas projetadas pelo paisagista Roberto Burle Marx.

Para a Prefeitura do Recife, responsável pela manutenção dos jardins, a restauração de jardins era algo incomum e, portanto, novo no planejamento. A restauração da praça Euclides da Cunha foi concluída em 2004; a da praça Faria Neves em 2006; a da praça do Derby em 2008. (SÁ CARNEIRO; SILVA, A.; VERAS, 2013). Além desses jardins, também compõem a obra de Burle Marx no Recife, a praça de Casa Forte (1935), o conjunto Jardim do Palácio do Campo das Princesas e praça da República (1936) e o jardim do aeroporto dos Guararapes (1957), considerados os mais significativos pelo seu estado de conservação².

Em 1989 o curso de licenciatura em Arquitetura Paisagista do Instituto Superior de Agronomia (ISA) da Universidade de Lisboa iniciou a disciplina de Recuperação de Jardins Históricos.

2 Pernambuco conta com 58 projetos de Burle Marx, entre públicos e privados (SÁ CARNEIRO; SILVA, A.; SILVA, J., 2013). 
Desse conjunto de jardins, tombados pelo Instituto do Patrimônio Histórico e Artístico Nacional (Iphan) como patrimônio cultural, o jardim do Aeroporto foi escolhido como estudo de caso do workshop "Restauro de Jardins Históricos"3, organizado pelo Laboratório de Paisagem/UFPE em 2012, envolvendo alunos e profissionais das áreas de arquitetura e urbanismo, biologia, agronomia, engenharia florestal e engenharia civil, totalizando vinte e quatro pessoas e uma banca examinadora de quatro arquitetos da área de paisagismo e de patrimônio: Alexandre Campello, Luiz Vieira, Fabio Cavalcanti e Inês Mendonça de Oliveira.

A praça Ministro Salgado Filho está situada no bairro do Ibura, no Recife, em frente ao aeroporto Internacional dos Guararapes, com área de 1,6 hectares. No momento do workshop, encontrava-se em quase abandono.

O workshop teve como objetivo discutir as regras e metodologias de restauro em nível internacional, observando os problemas específicos do caso de estudo que serviriam de referência para as intervenções nos jardins de Burle Marx no Recife. Baseou-se na Carta de Florença, no Inventário dos jardins de Burle Marx no Recife ${ }^{4}$, na experiência do Laboratório da Paisagem/UFPE relacionada à restauração de jardins do paisagista, e considerou a conjuntura administrativa local a serviço desse patrimônio.

Os conceitos de restauração e conservação de jardins históricos foram abordados no workshop de forma científica, no âmbito da preocupação e discussão sobre restauro do patrimônio cultural que a UNESCO impulsionou ao ser instituída a categoria de paisagem cultural ${ }^{5}$ como patrimônio da humanidade (1992), uma vez que nela se inserem os jardins históricos. $\bigcirc$ jardim é mencionado na categoria de "paisagens claramente definidas", que são as desenhadas e criadas intencionalmente pelo homem por razões estéticas, sociais e recreativas. (FOWLER, 2003). Como exemplo, menciona-se o Jardim Botânico de Kew, na Inglaterra, e o Jardim de Versalhes, na França. Antes disso, a intervenção no jardim estava subjugada à edificação histórica/monumento, que, por ser o motivo principal, subordinava o jardim como entidade patrimonial menor.

A sistematização dessa experiência significa um momento de avaliação dos procedimentos adotados e dos resultados obtidos para galgar outro nível de conhecimento e rigor nas futuras solicitações. Isso implica em maior firmeza na consolidação de uma equipe interdisciplinar, com profissionais treinados para elaborar planos de conservação para os jardins tombados.

3 Ministrado pela professora e arquiteta-paisagista Cristina Castel-Branco (Instituto Superior de Agronomia da Universidade de Lisboa), que vem coordenando o restauro de jardins históricos em Portugal desde 1989; o workshop aconteceu nos dias 3, 4 e 5 de dezembro de 2012.

$4 \quad \bigcirc$ Inventário dos Jardins de Burle Marx no Recife, elaborado pelo Laboratório da Paisagem da UFPE, teve início em 2008 e foi concluído em 2012. Trata dos seis jardins hoje tombados como Patrimônio Cultural Nacional pelo Iphan.

5 " [...] associação entre os aspectos culturais e naturais [...] ilustrativas da evolução da sociedade humana e seus assentamentos ao longo do tempo, sobre a influência de contingências físicas e/ou oportunidades apresentadas pelo ambiente natural, bem como pelas sucessivas forças social, econômica e cultural, que nelas interferem". (RIBEIRO, 2007, p. 41). 


\section{RESTAURAÇÃO DE JARDIM HISTÓRICO}

A ideia moderna de restauração, construída no início do século XX, deve-se ao arquiteto restaurador Camillo Boito, que, conforme Kühl (2008), teve participação decisiva na elaboração de conteúdo para a historiografia da restauração, assumindo posição moderada e intermediária entre o pensamento de Viollet-le-Duc e o de John Ruskin. Em 1883, Boito participou do Congresso de Engenheiros e Arquitetos em Roma, mas iniciou seu trabalho como restaurador em 1858, fazendo o estudo documental da obra a partir de desenhos e fotografias, priorizando a forma e a técnica construtiva, fazendo uso da observação.

Enquanto a opinião de John Ruskin era de respeitar a matéria original e deixar seguir as transformações da obra ao longo do tempo, mas defendendo as precauções de conservação para evitar a degradação, a de Viollet-le-Duc defendia a necessidade de trazer de volta o aspecto inicial da obra sem basear-se em algo palpável, porém mantendo o caráter de herança viva. No texto "Os restauradores" duas posições, observando que se deveria adotar a conservação do monumento na sua forma original para evitar a restauração, mas admitindo-a como mal necessário, enfatizando a necessidade de deixar distinta a expressão contemporânea de intervenção. (BOITO, 2008).

Contribui também, com grande repercussão no debate, o especialista italiano $\mathrm{Ce}$ sare Brandi (2004), autor de Teoria da restauração, lançado em 1963, que atrela a condição de "obra de arte" ao objeto a ser restaurado. Como explica Giovani Carbonara, responsável pela introdução desse livro, a obra de arte pode ser uma pintura, uma escultura, uma expressão arquitetônica, mas também um centro histórico ou uma paisagem, que seriam analisados segundo as instâncias histórica e estética. Ao considerar a paisagem, Brandi interpõe uma aproximação com o jardim histórico.

Em se tratando de jardins, Berjman (2011) afirma que já no século XVIII começaram a restaurar os primeiros jardins antigos e, no século XIX, com base nos estudos produzidos, o paisagista francês Edouard André propõe a criação da categoria "jardim histórico". Ainda em 1895, é criada a National Trust, na Inglaterra, com especialistas em jardim e paisagem.

Em 1971, acontece o primeiro Congresso Internacional sobre jardins históricos, em Fontainebleau, França (AÑON FELIÚ, 2005), e em 1972, é reelaborada a Carta de Restauro Italiana, a partir do pensamento de Brandi, ampliando a noção de patrimônio para jardins e parques.

A preocupação com a natureza específica do jardim histórico e sua restauração, com o objetivo de protegê-la, é devidamente abordada na Carta de Florença, que determina no Art. 2:

Resultado de uma conferência realizada na exposição de Turim, em 1884, direcionada à arquitetura, pintura e escultura. 
O jardim histórico é uma composição de arquitetura cujo material é principalmente vegetal, portanto, vivo, e, como tal, perecível e renovável. Seu aspecto resulta, assim, de um perpétuo equilíbrio entre o movimento cíclico das estações, do desenvolvimento e do definhamento da natureza, e da vontade de arte e de artifício que tende a perenizar o sev estado.

Outro artigo da Carta enuncia a importância da fidelidade ao desenho original do jardim como valor de patrimônio, conteúdo devidamente tratado nas discussões do workshop realizado no Recife. Para a restauração do jardim "[...] é preciso aliar-se à marca de quem o concebeu, de quem o construiu, e de quem o manteve, e respeitá-la como um fator tão fundamental como os processos naturais, e certamente mais importantes que a própria intervenção de restauro". (MONTEIRO; CASTEL-BRANCO; FONSECA, 1999, p. 143). Isso significa possibilitar o reconhecimento da ideia do paisagista a partir do resgate dos seus princípios projetuais e segundo os limites do material existente. Assim, a ideia do paisagista estará mantida e, por isso, os ajustes justificam-se.

A especialista Carmem Añón Feliú (1995), que participou da elaboração da Carta de Florença e que, conforme Beriman (2011, p. 34), "[...] estableció una metodología de estudio y restauración de los jardines históricos que se há convertido en modelo", salienta o tempo como um elemento de composição do jardim, dada a sua efemeridade. Conforme a autora, o paisagista fornece a matéria, permitindo ao tempo agir sobre o jardim, o que não significa aceitar a sua descaracterização. Nesse sentido, ressalta o caráter ético da restauração de um jardim, que traz à discussão as questões da autenticidade e da integridade.

A autenticidade de um jardim avalia os componentes de origem, aspectos de comparação, dos materiais, das tecnologias, da simbologia e do entorno, no momento da criação, e os efeitos da ação do tempo, incluindo uso e valor social até o momento atual. (DELPHIM, 2005). No caso do jardim, é preciso lembrar sua condição de material perecível e renovável, como destaca a Carta de Florença. Já a integridade, refere-se à completude do bem, no sentido do equilíbrio entre os elementos componentes. (DELPHIM, 2005).

Para alcançar esse nível de complexidade do jardim, a Carta de Juiz de Fora (2010) salienta a formação de profissionais e a interdisciplinaridade da equipe responsável como necessidades primordiais para a elaboração do projeto de restauração, exigindo conhecimentos arquitetônicos, urbanísticos, biológicos, arqueológicos, artísticos e históricos, e conhecimentos técnicos do executor, que é o jardineiro.

No caso da conservação dos jardins históricos, Michel Conan (2003) expressa preocupação no que diz respeito aos ecossistemas e à componente histórica do jardim:

[...] o dilema que a conservação da história e da biodiversidade impõe às organizações internacionais nas definições legais de conservação dos jardins. Em nome da história, os jardins enquanto legado cultural devem ser protegidos da erosão e da invasão das forças destrutivas da natureza; em nome da biodiversidade, os jardins enquanto biótopos devem ser protegidos da interferência humana. (CONAN, 2003, p. 13). 
É frequente colocar esse dilema durante o processo de restauro de jardins históricos - e ainda mais nos jardins de Burle Marx, com plantas tropicais e destaque para as águas, nos quais a diversidade vegetal se sobrepõe aos elementos construídos.

A metodologia escolhida por Cristina Castel-Branco para direcionar a discussão sobre as linhas gerais do projeto de restauração da praça Ministro Salgado Filho baseou-se nos fundamentos propostos por Carmen Añón Feliú referenciados no texto El jardín histórico: notas para una metodología previa al proyecto de recuperacíon, publicado no Journal Scientifique de 1993, com apoio do ICOMOS, no qual estabelece quatro ideias fundamentais em toda restauração: i) ser fiel à origem do jardim, o que exige observação intensa e estudos para descobrir seu próprio encanto; ii) respeitar o tempo, entendendo-o como um elemento criador do jardim; iii) valorar os aportes, ou seja, avaliar os elementos introduzidos e que passaram a fazer parte da composição original; iv) evitar dissonâncias, para não interferir na composição estética e histórica.

Para a referida especialista, há quatro grandes fases para o desenvolvimento do trabalho: i) análise e documentação - estudo do passado e do presente; ii) critérios; iii) projetos; iv) atuações complementares, referindo-se a uma política de conservação para assegurar sua mensagem. Tais fases corroboram com as especificações do Art. $15^{\circ}$ da Carta de Florença de 1981, que diz:

Qualquer restauro e, com mais forte razão, qualquer reconstituição de um jardim histórico só serão empreendidas após um estudo aprofundado, que vá desde as escavações até a coleta de todos os documentos referentes ao respectivo jardim e aos jardins análogos, suscetível de assegurar o caráter científico da intervenção.

cumprimento dessas quatro fases dará segurança e profundo conhecimento do jardim e de seus problemas, resultando em algo mais robusto quando chegar o momento de executar o projeto. As quatro fases foram aplicadas durante o restauro do Jardim Botânico da Ajuda (Portugal), obra na qual os princípios da Carta de Florença e os postulados de Carmen Añón Feliú foram experimentados por Cristina Castel-Branco entre 1994 e 1997. Essa nova abordagem científica para o restauro de jardins históricos foi apresentada durante o workshop e na discussão das linhas gerais do projeto de restauração da praça Ministro Salgado Filho, servindo de fio condutor.

\section{O JARDIM HISTÓRICO ANALISADO: A PRAÇA MINISTRO SALGADO FILHO NO AEROPORTO DOS GUARARAPES}

O projeto da praça Ministro Salgado Filho foi concebido pelo paisagista Roberto Burle Marx em 1957, como parte de um conjunto arquitetônico moderno juntamente ao edifício do aeroporto dos Guararapes, o que viria a ser ponto de atração para residentes e turistas. Naquele momento, Burle Marx formava um grupo com outros profissionais, inclusive estrangeiros, que também ficou responsável por dois projetos de grande impacto urbano: o do parque del Este, em Caracas, e o do parque do Flamen- 
go, no Rio de Janeiro. O grupo reunia os arquitetos Fernando Tábora, John Sttodart, Júlio Cesar Pessolani e Maurício Pesavento. O projeto do edifício do aeroporto ficou sob a responsabilidade do arquiteto Arthur Mesquita, contendo, também, um painel do artista pernambucano Lula Cardoso Ayres. Esse notável empreendimento, inaugurado pelo prefeito Pelópidas Silveira em 1957, passou a ser uma das imagens identificadas como cartões-postais do Recife. Nesse jardim, assim chamado por Burle Marx, havia, segundo um dos depoimentos concedidos pelo prefeito, vários tipos de plantas regionais. (DIÁRIO DE PERNAMBUCO, 1957).

O projeto do conjunto compreendia uma unidade plástica de caráter modernista que tinha como ponto focal o espelho d'água com vegetação aquática. Desse lago, de formas curvas, configurou-se o traçado que inovava pela forma e surpreendia pelo movimento e reflexo favorecendo a contemplação e permitindo bom crescimento das espécies vegetais nos vários estratos e em diferentes pontos. Ao longo do tempo, a praça permaneceu como referência, como um cartão-postal para os recifenses, pela beleza artística de sua composição, tendo a vegetação e a água como elementos dominantes e exercendo a função de ambiente de recepção para os visitantes e de convívio para os residentes da cidade (figuras 1 e 2).

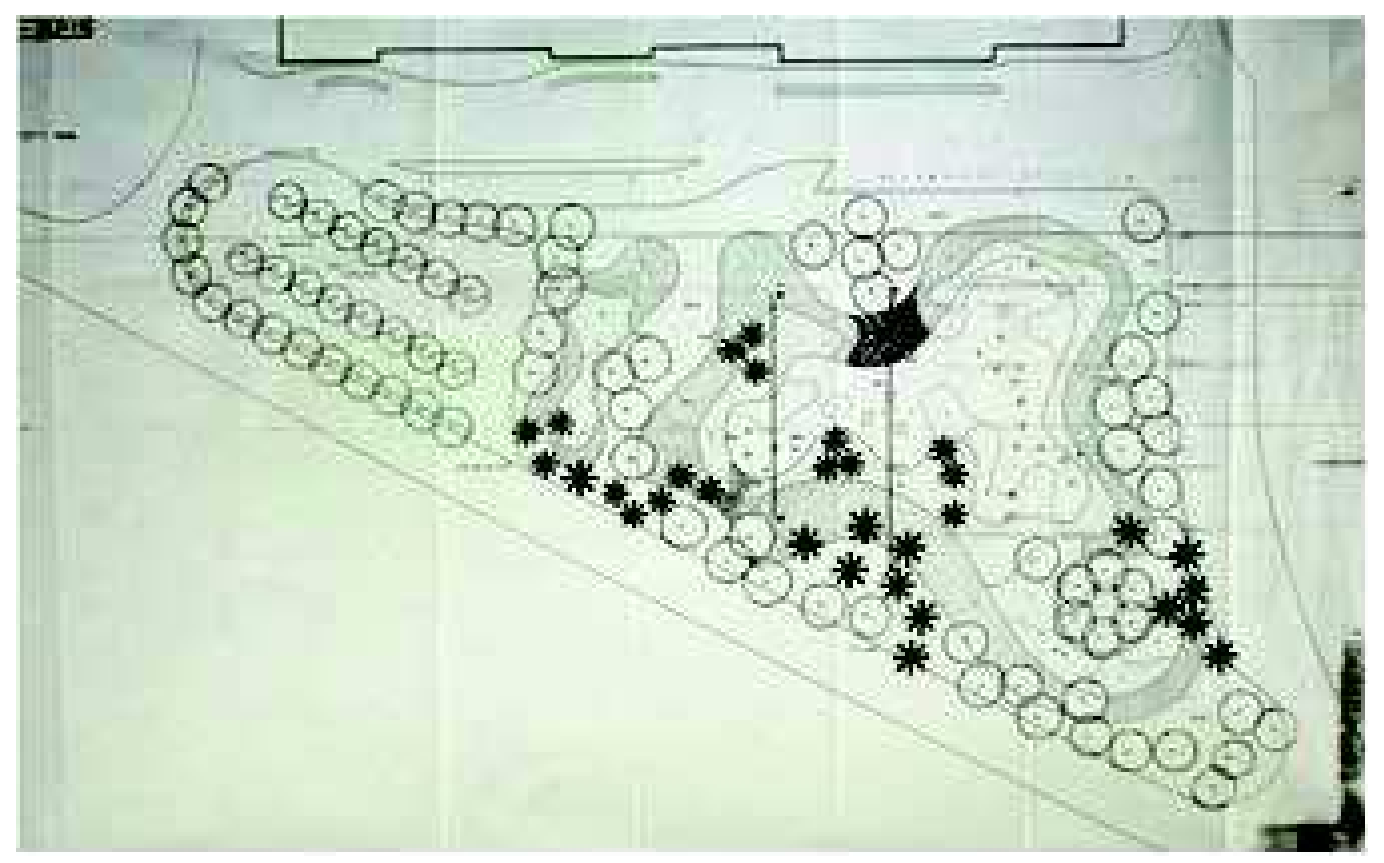

Figura 1 Fotografia do projeto original de ajardinamento do aeroporto Ministro Salgado Filho, 1957. Foto: Acervo Burle Marx Escritório de Paisagismo.

A convergência para o lago valorizou a água e a vegetação e ofereceu abertura para o reflexo do entorno e da edificação, confirmando a integração plena entre os dois objetos urbanos como unidade. Distribuída em quatro estratos, a vegetação compõe espaços e, sobre o lago, cria manchas em diferentes cores, texturas e escala, insinuando uma pintura artística. Recantos que despertam as mais variadas sensações podem ser 


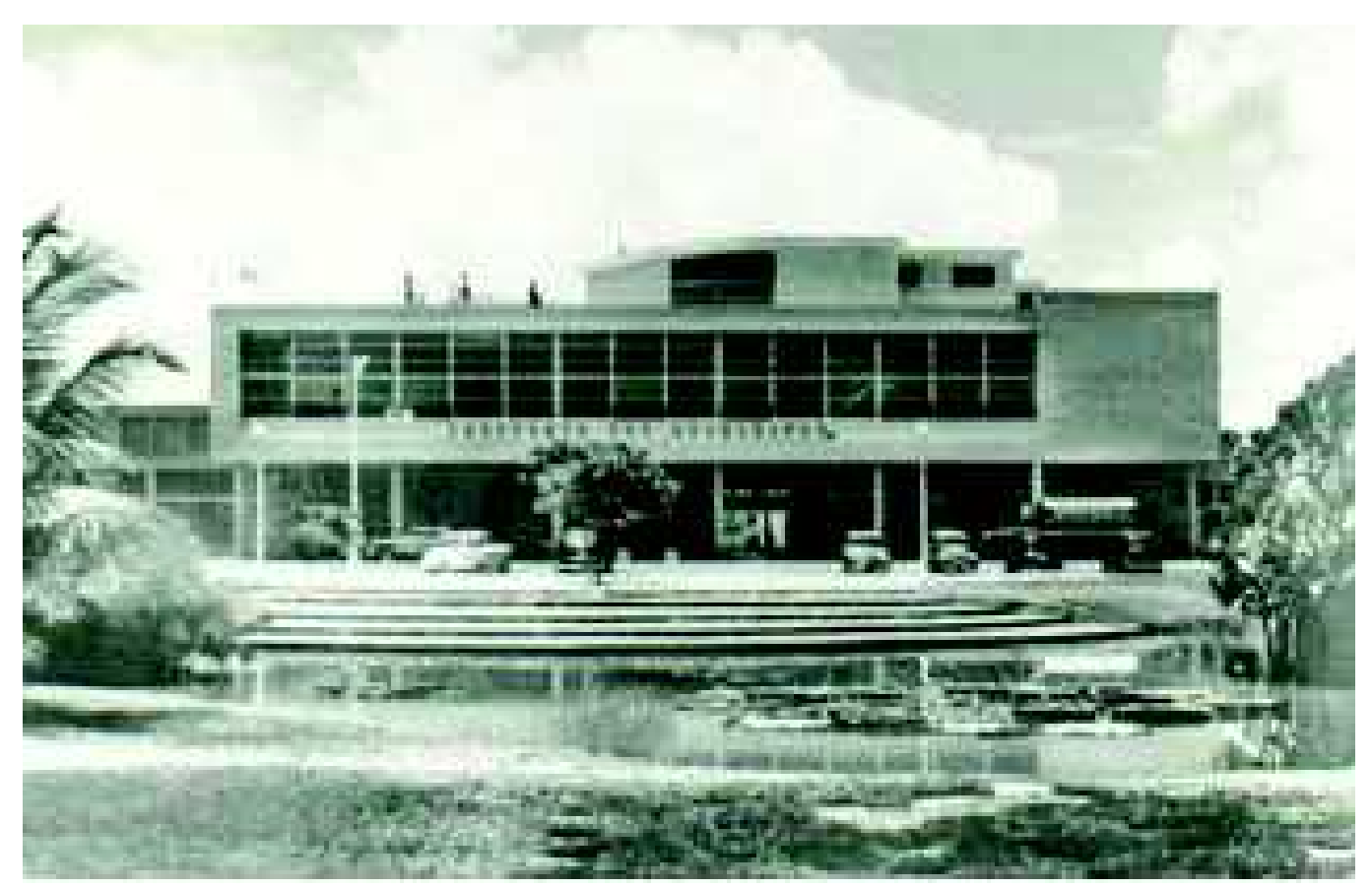

Figura 2 Jardim do aeroporto, 1958.

Foto: Acervo do Laboratório da Paisagem/UFPE.

desfrutados - seja quando degraus adentram o espelho d'água e permitem perceber o formato escultural do conjunto de aninga (Montrichardia linifera), complementado, mais ao fundo, pelas amplas copas dos abricós-de-macaco (Couroupita guianensis) -, seja no ato de caminhar pelos caminhos ondulantes e perceber a diversidade de palmeiras, como a macaibeira (Acrocomia intumescens), o açaí (Euterpe edulis) e o aricuri (Attalea butyracea), que se entrelaçam por entre os ipês (Tabebuia heptaphylla), os paus-reis (Basiloxylon brasiliensis) e as sibipirunas (Caesalpinia peltophoroides). A área da praça complementava-se com um estacionamento bastante arborizado com indivíduos de oiti (Licania tomentosa).

Em 1974, segundo projeto da Prefeitura do Recife, o estacionamento do projeto original (figura 3) foi retirado e o espaço recreativo da praça foi ampliado com a implantação de canteiros, área gramada e bancos semelhantes àqueles indicados pelo paisagista no mesmo projeto (figura 3). Uma última intervenção, em 1993, manteve os princípios do projeto de Burle Marx, mas sem recuperar o estacionamento e com pequena substituição de algumas espécies vegetais. Desde a instituição da Lei $N^{\circ}$ 16.414 de 1998, a praça está situada na Zona Especial do Aeroporto (ZEA) e, devido ao tráfego aéreo, tem restrições de gabarito.

Em 2000, a ampliação do aeroporto resultou em obra de grande impacto pela extensão da área construída, o que exigiu adequação do traçado viário, implicando na construção de dois viadutos. $O$ sistema viário do entorno do novo aeroporto Internacional dos Guararapes Gilberto Freyre transformou a praça numa ilha de tráfego quase inacessível ao convívio social e a relação com o antigo edifício do aeroporto 
deixou de existir, pois o acesso principal foi mudado. Com isso, o jardim - outrora tão vivenciado pelo público - foi esquecido.

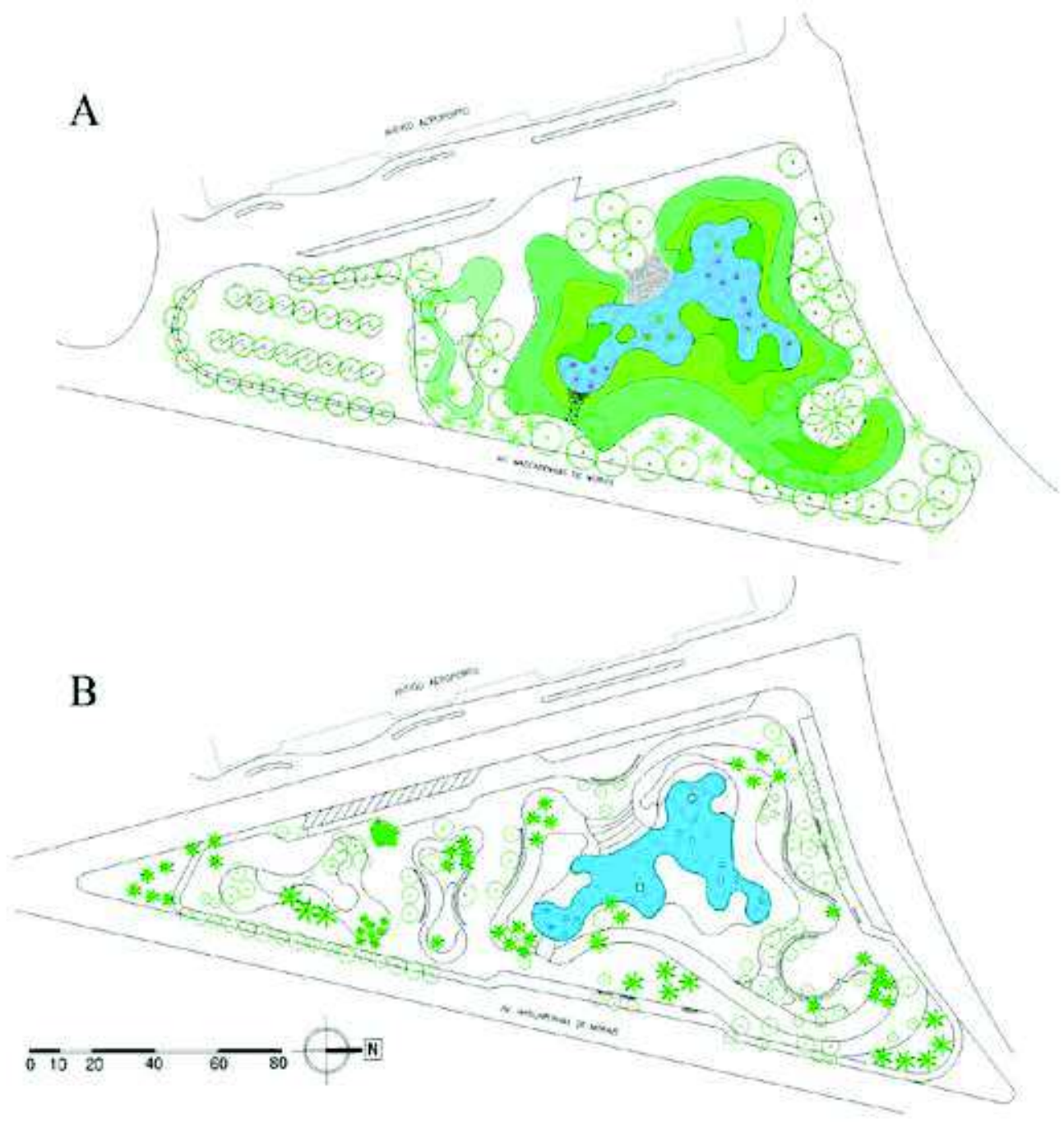

Figura 3 Praça Ministro Salgado Filho. Comparação entre dois momentos. Em A, projeto original (1957); em B, projeto de remodelação elaborado pela Prefeitura do Recife (1974). Desenho de Wilson de Barros Feitosa Júnior, 2015.

A dificuldade de acesso e a falta de conservação restringiram seu uso às pessoas que aguardavam os ônibus nos pontos de parada e àquelas que circulavam de modo ocasional, muito provavelmente, apenas durante o dia. Por outro lado, esse uso pontual e específico favoreceu a instalação de comércio informal e a apropriação da área por moradores de rua que danificavam a vegetação arbórea por acender fogueiras junto às arvores e guardar, nos troncos "ocos", materiais de uso pessoal. Há o agravante dos ruídos dos transportes nas vias de intenso tráfego interestadual e do aumento de polvição, que provocam sérias ameaças à cobertura vegetal já bastante escassa. 
Mesmo tendo sido adotada pela Empresa Brasileira de Infraestrutura Aeroportuária (Infraero), de 2000 a 2008, o precário estado de conservação em que a praça se encontrava até 2008 fomentou a elaboração do projeto de restauração pela Prefeitura do Recife e pelo Laboratório da Paisagem/UFPE (figura 4).

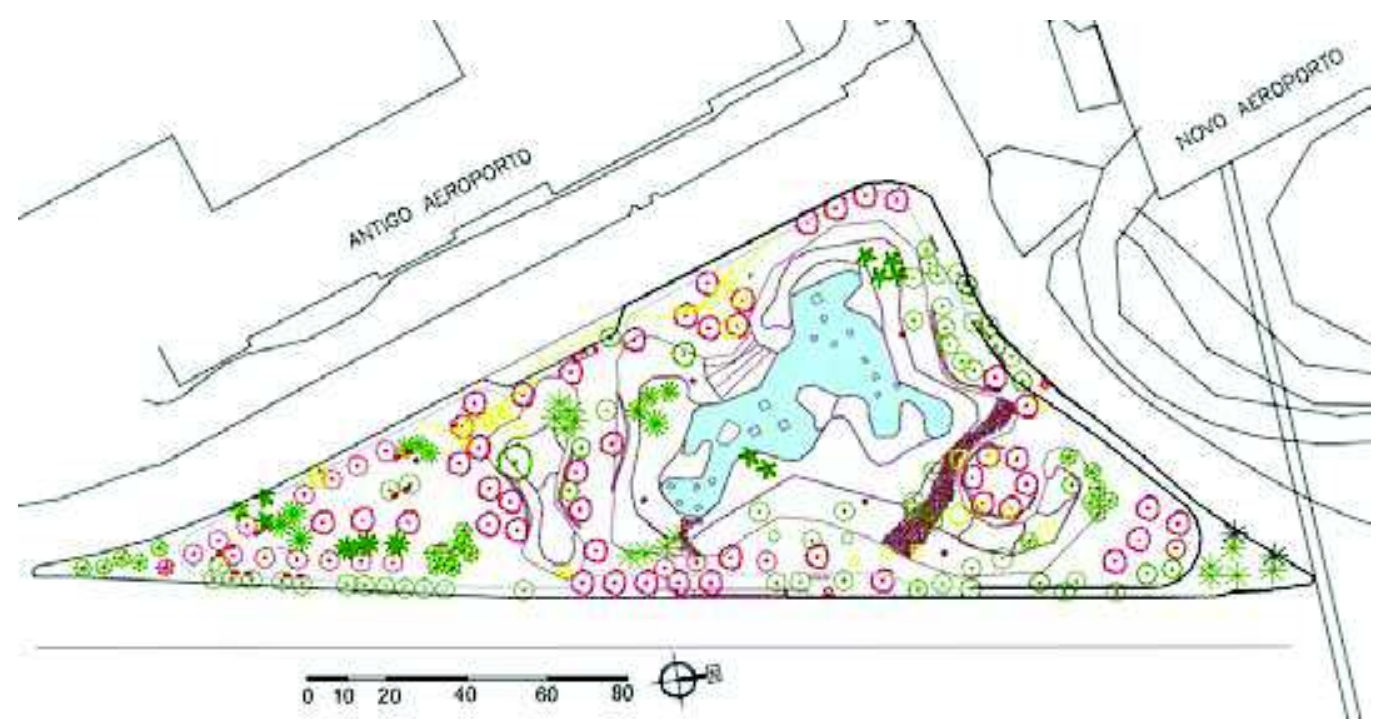

Figura 4 Projeto de restauração da praça Ministro Salgado Filho, 2009. Desenho de Wilson de Barros Feitosa Júnior, 2015.

Nesse mesmo ano, por conta da falta de conservação de outros jardins de Burle Marx, já restaurados, o Laboratório da Paisagem/UFPE decidiu solicitar ao Iphan o tombamento de seis jardins projetados pelo paisagista, incluindo a praça Ministro Salgado Filho, para se tornarem patrimônio cultural nacional.

O projeto de restauração concretizou-se somente em agosto de 2013, portanto, após o workshop (ocorrido em dezembro de 2012), e tomou como ponto de partida o projeto de 2009, no qual se priorizou a vegetação indicada no projeto original de Burle Marx com especial atenção para as plantas aquáticas. Recompôs-se o desenho do lago e dos canteiros no seu entorno e consolidou-se um caminho usado pelos que trabalham nas proximidades, do terminal de ônibus até a edificação nova do aeroporto.

Em reuniões com técnicos da Prefeitura do Recife, foi ressaltada a necessidade de elaboração e implantação de um Plano de Gestão da Conservação que definisse as diretrizes e os procedimentos necessários.

\section{O DESENVOLVIMENTO DO WORKSHOP}

Para atingir o objetivo proposto, a arquiteta paisagista Cristina Castel-Branco adaptou ao projeto de restauro o método que o professor Carl Steinitz aplica ao ensino do projeto em arquitetura paisagística na Universidade de Lisboa. $\bigcirc$ "6-step method" baseia-se em seis modelos distintos que orientam uma equipe bem organizada a decidir por várias 
soluções, garantindo intensa participação. "É um método transdisciplinar que integra não só a participação de profissionais, mas também do público. Esta metodologia [...] consiste nas seis questões fundamentais que todo e qualquer projeto, independentemente da escala de aplicação, precisa responder." (FREITAS, 2014, p. 41); (figura 5).

O método obriga a uma preparação prévia dos elementos cartográficos e da evolução histórica do jardim, o que foi garantido pela equipe do Laboratório de Paisagem/ UFPE. A adaptação ao método incidiu sobre o fato de dividir o grupo em equipes, como se tratasse de um ateliê, onde cada equipe conhece um setor da área. As cinco equipes basearam-se nos itens que são essenciais ao jardim histórico, e as análises que apresentaram ao fim de dois dias de trabalho foram notáveis.

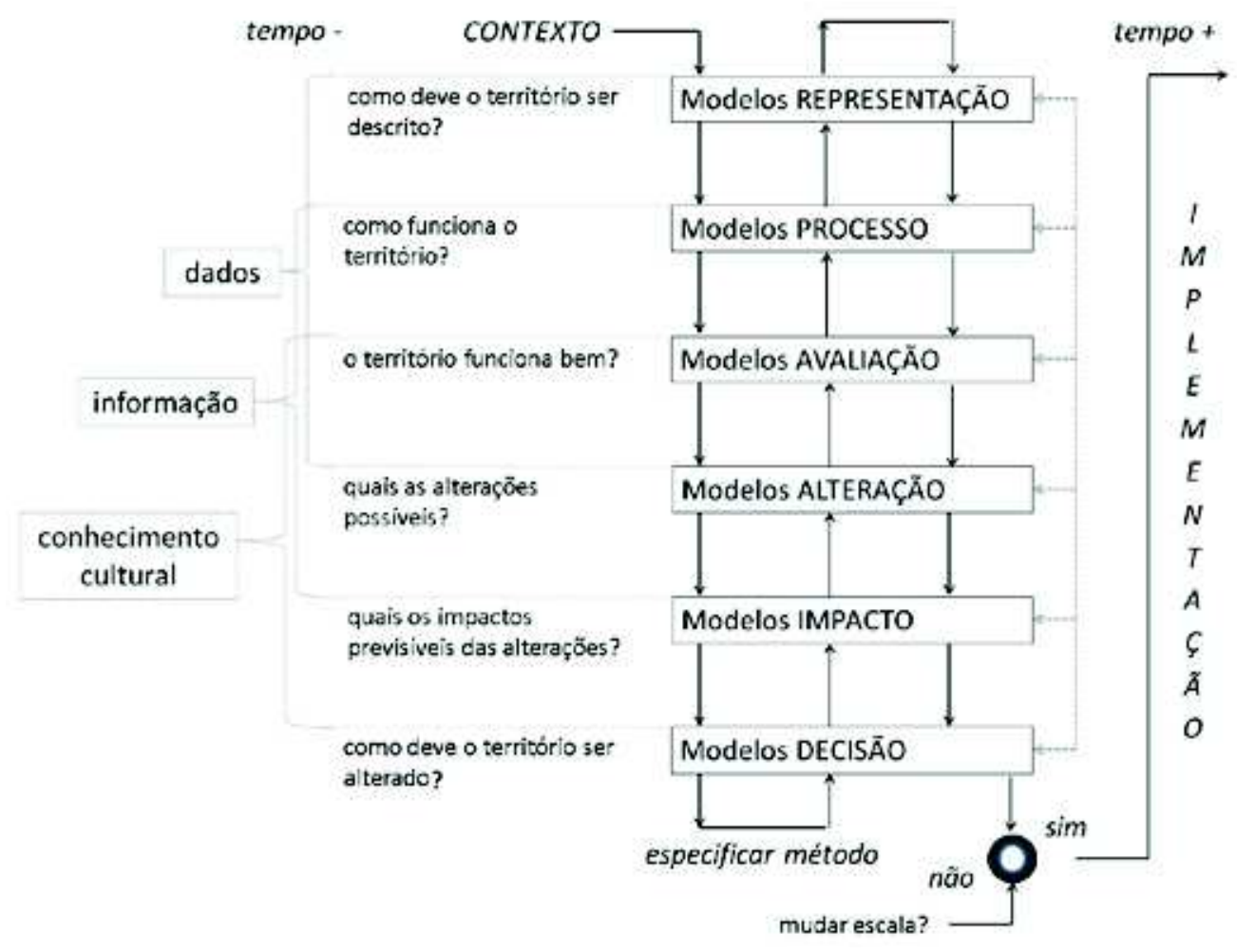

Figura 5 6-step method. Fonte: Freitas (2014, p. 41).

O workshop representou um momento oportuno para fomentar a reflexão e a discussão sobre o projeto de restauração da praça Salgado Filho elaborado em 2009, reforçou a importância da conservação dos jardins históricos de Burle Marx em vias de tombamento e intencionou contribuir com a capacitação necessária da equipe de profissionais envolvida na elaboração de um projeto de restauração de um jardim histórico e na sua conservação. Por essa razão, o Laboratório da Paisagem/UFPE convidou ao evento membros do Iphan, da Fundação do Patrimônio Histórico e Artístico de Pernambuco (Fundarpe), da UFPE e da Prefeitura do Recife, instituições envolvidas com o compromisso de salvaguardar esse patrimônio paisagístico. Foram intercaladas 
atividades de exposição teórica sobre jardim histórico e métodos de restauração, de visita de campo para conhecimento do objeto de intervenção e de trabalho prático em ateliê para análise do jardim e elaboração de propostas de restauração.

O conhecimento do jardim marca o início do trabalho de restauração. A relevância dessa etapa inicial está no fato de que, nas palavras de Cristina Castel-Branco, " [...] as soluções para o restauro encontram-se dentro do jardim. É preciso estudá-lo antes de começar a inventar soluções ${ }^{7}[. .]^{\prime \prime}$, argumento reforçado pelo Art. 15 da Carta de Florença de 1981 no que tange à necessidade de garantir o caráter científico da intervenção, o que exige estudo aprofundado, incluindo escavações e coleta de documentação.

O método de Steinitz exige análise cuidadosa, que permita representar o jardim nos seus múltiplos componentes - mobiliário, vegetação, água - e processos dinâmicos, para depois fazer um diagnóstico. Esses três passos foram iniciados durante a visita realizada pelas equipes, ensinando-as a "ver" com detalhe esses componentes, a relação com o todo, e a registrar o que acontecia no espaço público.

Para maior eficiência do procedimento de análise da praça Ministro Salgado Filho, os participantes foram divididos em cinco equipes, correspondendo às cinco dimensões essenciais para a compreensão do jardim em sua completude: 1. Dimensão histórica; 2. Dimensão construtiva; 3. Dimensão botânica; 4. Dimensão hidráulica; 5. Dimensão do entorno.

O conteúdo dessas dimensões aparece ao longo da Carta de Florença de 1981. O Art. 8 relembra que "Um sítio histórico é uma paisagem específica associada a um acontecimento memorável, como por exemplo: a celebração de um importante fato histórico, um mito famoso; um combate épico; ou o motivo de um quadro célebre". Ou seja, o jardim tem uma dimensão histórica, que ficou a cargo da equipe A; o Art. 4 aborda a composição arquitetural do jardim histórico, com destaque para o plano e os diferentes perfis do terreno, as massas vegetais - essências, volumes, jogo de cores, espaçamento e alturas -, que ficaram a cargo da equipe B. Elementos construídos ou decorativos couberam ao grupo $C$, e as águas moventes ou dormentes à equipe $D$. $A$ relação entre o jardim e o entorno imediato, mais precisamente a edificação, é abordada no Art. 7, que ressalta que o "[...] jardim histórico não pode ser separado de seu próprio meio ou ambiente urbano ou rural, artificial ou natural". A equipe $E$ encarregou-se de estudar o entorno e os seus processos.

Dessa forma, a praça Ministro Salgado Filho foi analisada pelas cinco equipes, contemplando as dimensões necessárias para a ampla compreensão do jardim. Munidas da planta do projeto original e da planta baixa atualizada para fins comparativos, as equipes foram a campo para realizar o levantamento de dados, observando também o uso e a apropriação dos usuários. Sabiam que teriam só um dia de análise dos elementos e dos processos para depois apresentarem o diagnóstico em dez minutos, de forma a garantir boa compreensão do problema a todo o grupo.

Na visita foram constatados problemas que ameaçavam a conservação da praça: ineficiência do sistema de drenagem, mobiliário deteriorado, vegetação com proble-

Palavras proferidas durante a palestra de abertura do workshop 3 dez. 2012. 
mas fitossanitários, alteração do traçado original e ausência de grande quantidade da vegetação originalmente proposta. Além disso, observou-se acentuado acúmulo de lixo no espelho d'água, introdução de elementos arquitetônicos que não dialogavam com a paisagem do jardim e implantação indiscriminada de cabeamentos na instalação de redes para o aeroporto, que, somados ao desconforto sonoro e à insegurança de quem permanece na praça, definem um quadro preocupante ligado a um bem cultural que compõe parte das referências da história da paisagem recifense (figuras 6 e 7).

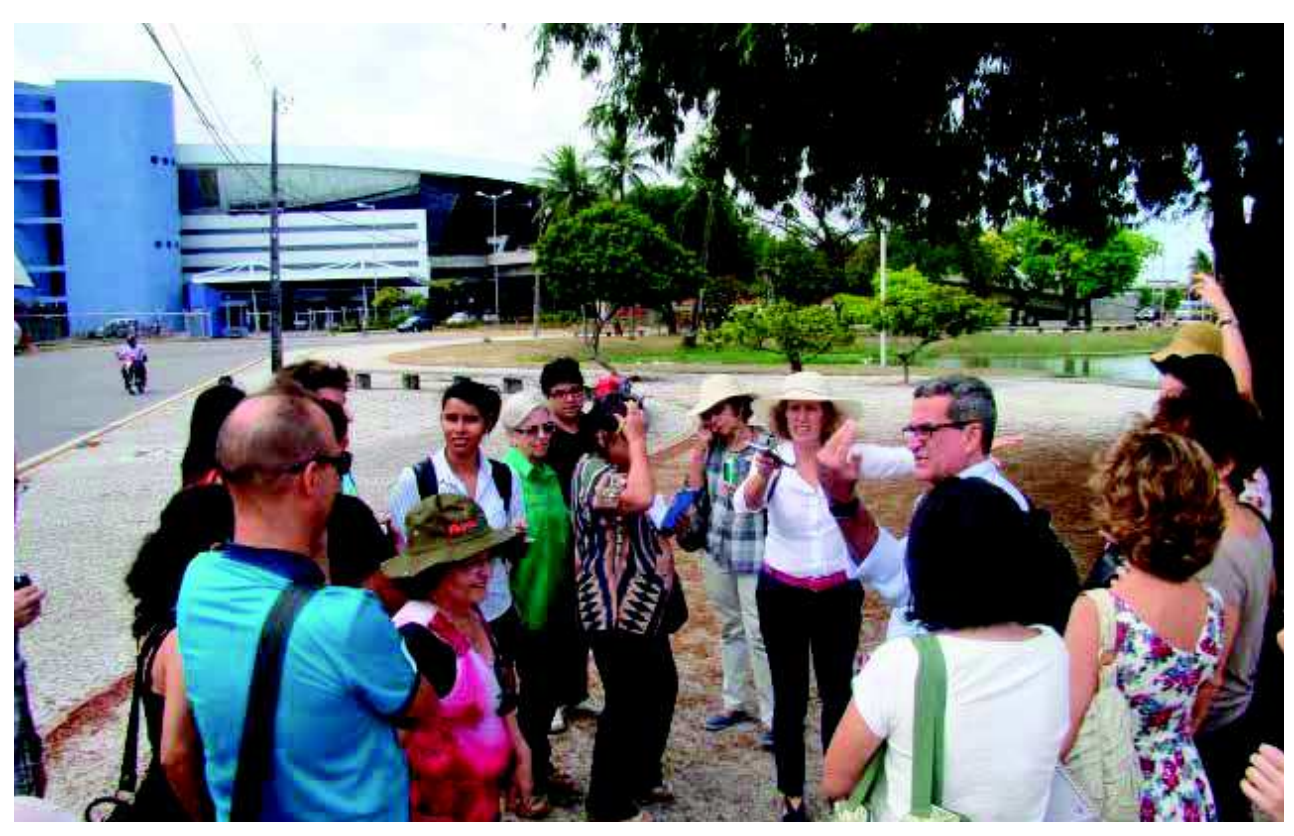

Figura 6 Visita técnica na praça Ministro Salgado Filho. Equipe do workshop. Foto: Joelmir Marques da Silva, 2012.

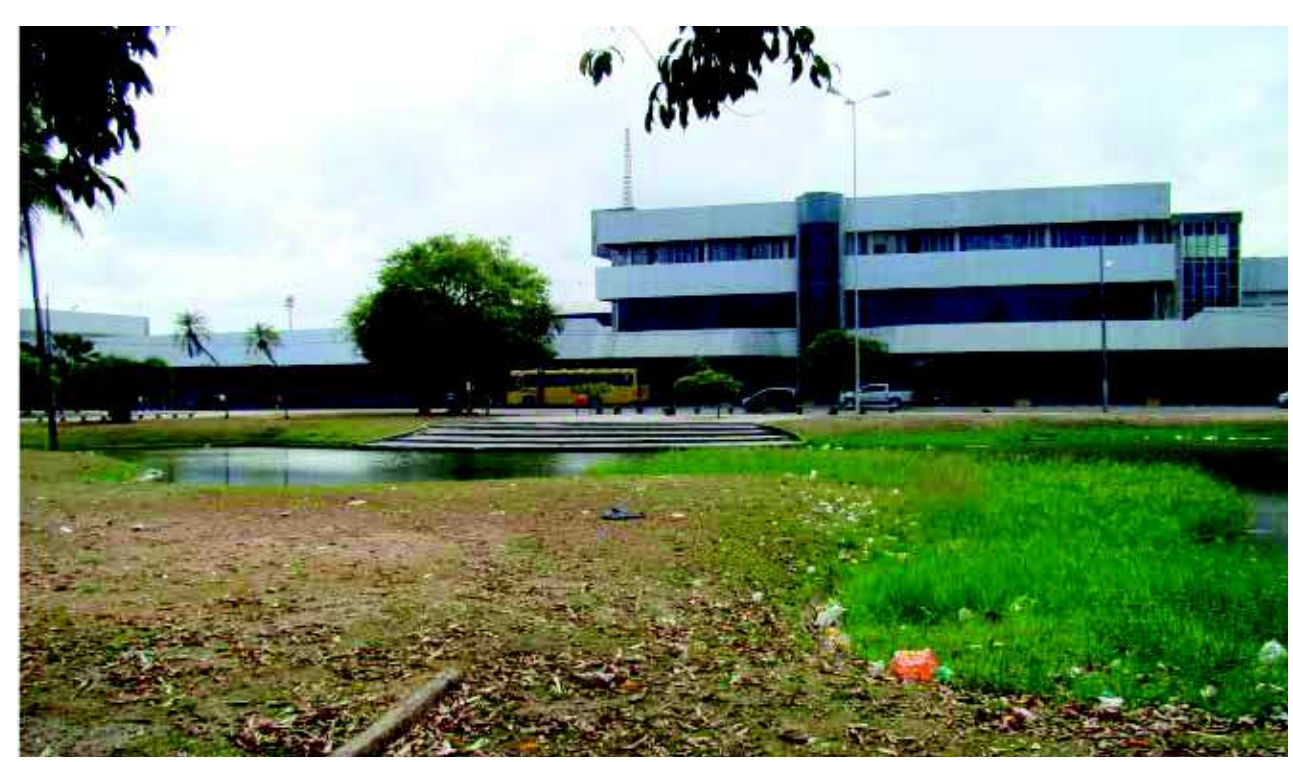

Figura 7 Visita técnica na praça Ministro Salgado Filho. Aspecto da falta de conservação da praça. Foto: Joelmir Marques da Silva, 2012. 
A análise dos elementos, dos processos e o seu diagnóstico tiveram continuidade nas atividades realizadas em ateliê no dia seguinte e foram encerradas com a apresentação das equipes, fazendo circular as informações referentes aos elementos do jardim histórico e à unidade de conjunto, como salienta o Art. 10 da Carta de Florença de 1981:

Qualquer operação de manutenção, conservação, restauro ou reabilitação de um jardim histórico, ou de uma das suas partes, deve tomar simultaneamente em consideração todos os seus elementos. Isolar as várias ações poderia alterar a unidade do conjunto.

Os diagnósticos apontaram, principalmente, para a fragmentação da relação entre o jardim e o edifício do antigo aeroporto e a sensação de desconforto sonoro procedente da circulação constante de veículos pesados e da interferência visual, que será provocada pela futura implantação de uma passarela suspensa, interligando o aeroporto à estação do metrô.

Após a exposição das análises e a discussão que se sucedeu, o método "6 step model" prevê que novas equipes sejam formadas e passem à fase de "mudança", ou seja, desenvolvam livremente e separadamente as propostas. Sendo assim, foram criadas cinco novas equipes, tendo cada uma delas um dos especialistas nos temas da análise $(A, B, C, D, E)$, formando equipes multidisciplinares. As equipes trabalharam mais um dia com vistas a desenvolver, cada uma, uma proposta de restauro baseada num conceito-chave, numa "ideia-força" para a alteração da praça Ministro Salgado Filho, visando a possíveis soluções para os problemas desta e do entorno (figuras 8 e 9).

Os conceitos guia mencionados direcionaram a intenção projetual de cada equipe, nomeando as propostas:

- um aeroporto com jardim: recompõe a relação entre o antigo aeroporto e o jardim mediante reativação da edificação com o novo uso e define fluxos e a requalificação nos usos das edificações adjacentes, como no caso das concessionárias de automóveis em frente à praça, restabelecendo suas conexões com o entorno;

- devolver o aeroporto ao jardim: teve como objetivo integrar o jardim com o entorno imediato, nivelando as cotas e tornando mais fluido o acesso ao antigo aeroporto; define como premissa oferecer espaços de permanência que protejam o usuário da intensidade do ruído existente no local, o qual deve servir como ponto de espera por ônibus;

- diálogo entre tempos: propõe o retorno do traçado original do projeto paisagístico de Burle Marx e a criação de jardins de transição na área que separa o jardim do novo aeroporto; a proposta de integração completa-se com a reabilitação do antigo aeroporto, composto por novo programa arquitetônico de usos, incluindo um restaurante-terraço com vista para o jardim; 
- integrar a memória de Burle Marx: agrega um projeto de comunicação visual - para divulgação da obra do paisagista - ao projeto paisagístico de restauração, como exercício de educação patrimonial por meio da concepção de totens informativos, localizados estrategicamente nos locais de circulação;

- praça para ser olhada: objetiva liberar as visadas para o jardim, explorando a visibilidade; trata os novos elementos urbanos como aliados, visando à apropriação por parte da população; dessa forma, justapõe uma estrutura vertical à nova passarela, construída para dar acesso ao aeroporto, possibilitando ao pedestre sua utilização como um belvedere, de modo a valorizar o jardim.

Os resultados foram apresentados em powerpoints e plantas que esquematizavam a solução de cada equipe para um júri especializado. $\bigcirc$ júri e os docentes avaliaram e explicaram as vantagens e problemas que cada proposta lhes sugeria. $O$ conceito que teve mais sucesso foi o "Integrar a memória de Burle Marx", que incluía um projeto de comunicação visual, por despertar no grupo participante a possibilidade de realizar o restauro do jardim fazendo homenagem mais significativa ao autor, com a divulgação de sua obra para o grande público.

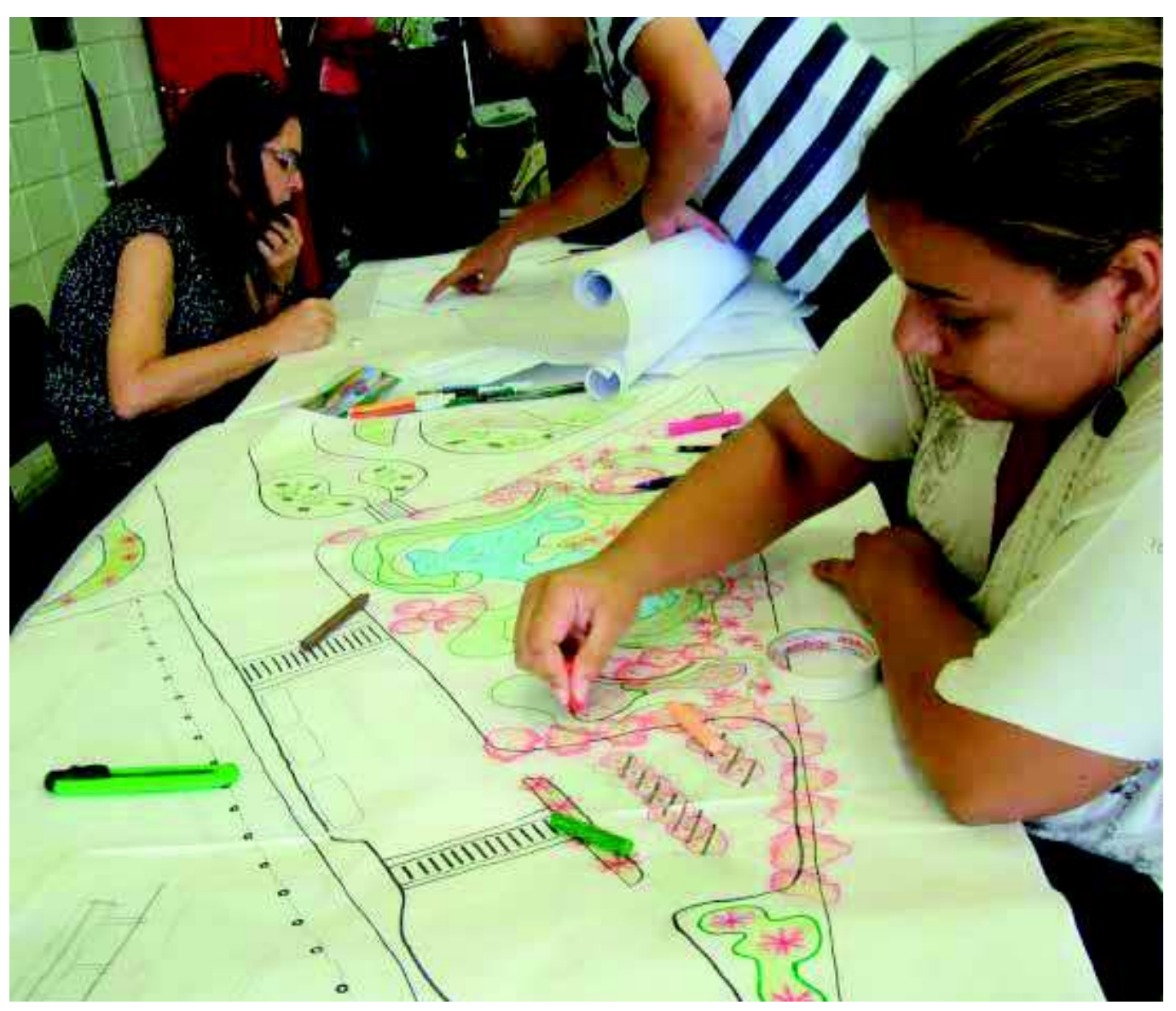

Figura 8 Atividades em ateliê. Elaboração das propostas. Foto: Ana Rita Sá Carneiro, 2012. 


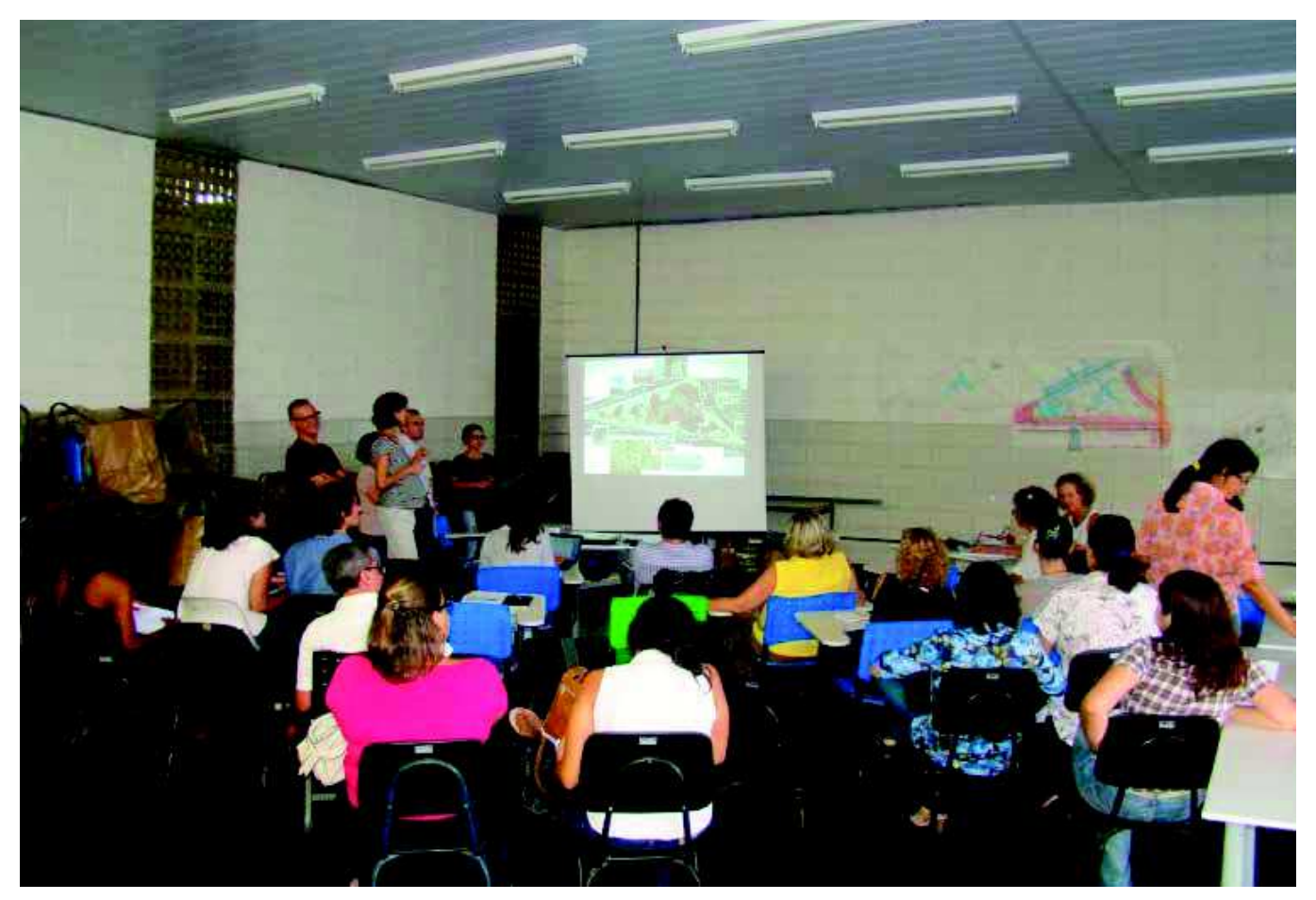

Figura 9 Atividades em ateliê. Apresentação e discussão das propostas. Foto: Joelmir Marques da Silva, 2012.

Apesar das especificidades de cada proposta, todas coincidiam na necessidade de retomar a relação com a edificação do antigo aeroporto, considerando que o projeto paisagístico de Burle Marx de 1957 tinha relação direta com a edificação; na necessidade de restaurar o lago, de repor as espécies botânicas especificadas no projeto original, compreendendo a vegetação como elemento principal do jardim que é um "Monumento Vivo" (CARTA DE FLORENÇA, 1981); na minimização dos impactos negativos causados pela circulação de veículos em alta velocidade, indicando a implantação de redutores de velocidade, e pela inserção da passarela. A criação de acessos diretos para o jardim a partir da passarela foi proposta com a finalidade de fortalecer o uso turístico. Também foi consensual a recomendação da criação de um bosque no lugar do estacionamento, presente no projeto original para proteger o espaço interior dos ruídos provocados pelos veículos, dada a ampliação do sistema viário.

Essa avaliação e a coincidência de elementos das várias propostas constituem um programa de trabalho que poderia servir de base para um projeto de restauro. De fato, um dos membros do júri, a arquiteta da Prefeitura do Recife, Inês Oliveira, durante o ano de 2013 incorporou sugestões da discussão do workshop ao projeto de restauro para a praça, elaborado em 2009, que permitiu recuperar o espelho de água e a vegetação aquática como atrativos mais significativos e melhorar os passeios e a arborização, criando ambiente mais acolhedor para os futuros usuários. Dessa forma, a restauração do jardim, realizada em 2013, recompôs a vegetação recomendada pelo paisagista para os canteiros e para o lago, mantendo a integridade desse jardim histórico. 


\section{CONCLUSÃO}

A experiência do workshop contribuiu para aprofundar as reflexões, incluindo novos critérios de análise e métodos expeditos para alicerçar o projeto de restauração da praça Ministro Salgado Filho de 2009. Representou, também, um momento de pensar o restauro de jardins históricos fundamentando-o num método claro de restauração, permitindo o input equitativo de várias áreas disciplinares com vistas ao estímulo de ideias a serem discutidas, retidas ou eliminadas, mas todas debatidas para melhorar o tratamento do jardim histórico.

A desconstrução do jardim do ponto de vista da Dimensão história, da Dimensão construtiva, da Dimensão botânica, da Dimensão hidráulica e da Dimensão do entorno, para proporcionar o conhecimento da sua totalidade, possibilitou a compreensão de uma concepção de conjunto edifício/jardim como uma unidade. Cada dimensão foi devidamente explorada, em diferentes aspectos, e as informações repassadas para os demais grupos - o que desencadeava novas reflexões, buscando a articulação entre as partes. Por sua vez, a localização do conjunto edifício/jardim em meio à malha viária de tráfego pesado revelava duas partes isoladas, uma vez que o edifício estava ocioso, de portas fechadas, e, portanto, o diálogo não mais se fazia. Ficou evidente a necessidade de reativar o edifício para fazer renascer o uso social cotidiano a partir de uma continuidade espacial. A experiência em pauta também proporcionou comparações com as intervenções de restauração em outros jardins, realizadas entre 2004 e 2008. O workshop significou, de forma relevante, um avanço para a conservação dos jardins históricos no Recife e no Brasil.

\section{REFERÊNCIAS BIBLIOGRÁFICAS}

AÑÓN FELIÚ, Carmen. El jardín histórico: notas para una metodología previa al proyecto de recuperación. In: Jardins et sites historiques, Comité International des Jardins et des Sites Historiques, ICOMOS-IFLA. Unesco, Fundación Cultural Banesto. Madrid: Ediciones Doce Calles, 1993, p. 312-325.

. Authenticité jardin el paysage. Conferência de Nara sobre autenticidade. Convenção do Patrimônio Mundial. Japão. Novembro de 1994. ICCROM/ICOMOS, 1995.

. La restauración de los jardines históricos. In: SEMINÁRIO LA DOCTRINA DE LA RESTAURACIÓN ATRAVÉS

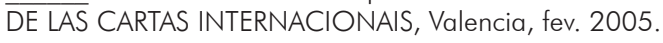

BERJMAN, Sonia. De los jardines históricos a los paisajes culturales: la labor de ICOMOS. In: TRINDADE, Jeanne; TERRA, Carlos. In: SIMPÓSIO ARQUEOLOGIA NA PAISAGEM/ ARQUEOLOGIA NA PAISAGEM: OLHARES SOBRE OS JARDINS HISTÓRICOS. Rio de Janeiro. Anais... Rio de Janeiro: Universidade Federal do Rio de Janeiro/Escola de Belas Artes: UFRJ, 2011.

BOITO, Camilo. Os restauradores. Tradução de Paulo Mugayar Kühl e Beatriz Mugayar Kühl. São Paulo: Ateliê Editorial, 2008.

BRANDI, Cesare. Teoria da restauração. Tradução de Beatriz Kühl. São Paulo: Ateliê Editorial, 2004.

CARTA DE FLORENÇA (1981). In: CURY, Isabelle (Org.). Cartas Patrimoniais. Rio de Janeiro: IPHAN, 2004.

CARTA DE JUIZ DE FORA. Instituto do Patrimônio Histórico e Artístico Nacional (Iphan), 2010.

CARTA DE VENEZA (1964). In: CURY, Isabelle (Org.). Cartas Patrimoniais. Rio de Janeiro: IPHAN, 2004.

CASTEL-BRANCO, Cristina (Org.). Jardim Botânico da Ajuda. Lisboa: Associação dos Amigos do Jardim Botânico da Ajuda e Livros Horizonte, 1999. 
Burle Marx no Recife: Restauro do Jardim do Aeroporto dos Guararapes como Bem Patrimonial

The origin of the profession of Landscape Architecture in Portugal during the Modern Movement. In: BIRNBAUM, Charles (Ed.). Preserving modern landscape architecture II: making postwar landscapes visible. Washington: Spacemaker Press, LLC, 2 v. 1, 2004, p. 110-117.

Os Jardins dos Vice-Reis Fronteira. Córdova: Oceanos, 2008.

; FONSECA, Mónica. Entrevista a Carl Steinitz. ArchiNews, Lisboa, Edição especial, 201 1, p. 100-115.

CONAN, Michel et al. Landscape design and the experience of motion. Washington DC: Dunbarton Oaks Research Library and Collection, 2003.

CONSEIL INTERNATIONAL DES MONUMENTS ET DES SITES (ICOMOS). Worldwide basic inventory: register card for Cultural Landscapes. Verbania: ICOMOS, 2006.

DELPHIM, Carlos Fernando de Moura. Intervenções em jardins históricos. Brasília: Iphan (manual), 2005.

Inauguração da Estação de Passageiros do Ibura até o mês de julho próximo, 20 mar. Diário de Pernambuco, 1957.

FONSECA, Mónica e CASTEL-BRANCO, Cristina. Entrevista a Carl Steinitz. ArchiNews, Lisboa, Edição especial, 2011 , p. 100-115.

FOWLER, Peter. World Heritage Cultural Landscapes 1992-2002. Paris: Unesco, 2003.

FREITAS, João. Metodologias de planeamento: análise comparativa. 2014. 82 f. (Dissertação em Arquitetura Paisagística), Licenciatura em Arquitetura Paisagista - Universidade de Lisboa, Lisboa, 2014.

KÜHL, Beatriz Mugayar. Os restauradores e o pensamento de Camillo Boito sobre a restauração. In: BOITO, Camilo. Os restauradores. Tradução de Paulo Mugayar Kühl e Beatriz Mugayar Kühl. São Paulo: Ateliê Editorial, 2008, p. 9-28.

LEENHARDT, Jacques (Org.). Nos jardins de Burle Marx. São Paulo: Perspectiva, 1994.

Lei $N^{\circ} 16.414$ de 29 de julho de 1998. Dispõe sobre as condições de uso e ocupação do solo na zona especial do aeroporto - ZEA e dá outras providências. Disponível em: <http://www.recife.pe.gov.br/pr/secplanejamento/ servicos/leis/lei16414.pdf>. Acesso em: 3 dez. 2012.

MONTEIRO, Antonio; CASTEL-BRANCO, Cristina; FONSECA, Luís. Restauro e manutenção: apogeu e declínio de um jardim. In: CASTEL-BRANCO, C (Coord.). Jardim Botânico da Ajuda. Lisboa: A.A.J.B.A. e Livros Horizonte, 1999, p. 143-169.

RACINE, Michel. Roberto Burle Marx, o elo que faltava. In: LEENHARDT, Jacques (Org.). Nos jardins de Burle Marx. São Paulo: Perspectiva, 1994, p. 105-117.

RIBEIRO, Rafael Winter. Paisagem cultural e patrimônio. Rio de Janeiro: Iphan/Copedoc, 2007.

SÁ CARNEIRO, Ana Rita; SILVA, Aline de Figueirôa; SILVA, Joelmir Marques. Jardins de Burle Marx no Nordeste do Brasil. Recife: UFPE, 2013.

; SILVA, Joelmir Marques; VERAS, Lucia Maria de Siqueira Cavalcanti. A paisagem como jardim: natureza da cultura urbana. In: VERRI, Gilda Maria Whitaker (Org.). Memorat, tecnociência, memória e cultura urbana na formação brasileira. Recife: UFPE, 2013, p. 49-65.

VIOLLET-LE-DUC, Eugène Emmanuel. Restauração. Tradução de Beatriz Mugayar Kühl. Cotia: Ateliê Editorial, 2006

Nota do editor

Submissão: 6 out. 2015

Aprovação: 21 jan. 2016 